\section{International Journal of Current Research in Medical Sciences}

ISSN: 2454-5716

WWw.ijcrims.com

Volume 2, Issue 10 -2016

\title{
Incidence of asymptomatic bacteriuria amongst female students residing in school hostels of Rivers state University of Science and Technology, Port Harcourt
}

\author{
Mbata C. A. ${ }^{1}$, Aleru C. P. ${ }^{1}$, Azike C. A. ${ }^{1}$, Adewoye M. O. ${ }^{1}$, Emeka E. E. ${ }^{1}$, \\ Ugwueze V. ${ }^{1}$ \\ Department of Medical Laboratory Science, Rivers State University of Science and Technology, \\ Nkpolu-Oroworukwo, Port Harcourt, Rivers State. \\ Corresponding Author: Mbata C. A., +2348033399278, E-mail: alfrose1@ yahoo.com
}

\begin{abstract}
The study was aimed at assessing asymptomatic bacteriuria among female students of Rivers State University of science and Technology (UST). Randomly sampled clean catch midstream urine specimens were collected from 100 apparently healthy asymptomatic undergraduate female students of RSUST between ages of 17 to 30 years. Urine was cultured on cysteine lactose electrolyte deficient agar (CLED) which is the gold standard for detecting asymptomatic bacteriuria and incubated overnight at $37^{\circ} \mathrm{C}$. Bacteria isolates were characterized and identified based on conventional microbiological techniques which include Grams and Biochemical reaction. The results showed that the total prevalence rate of bacteriuria was $78 \%$ with the highest rate occurring in students within age group of 21-23, 42(80.8\%). Out of the 78 bacteria isolates identified, $33(42.3 \%)$ were Escherichia coli, 22(28.2\%) were Staphylococcus aureus, 11(14.1\%) were Klebsiella pneumonia, 7(8.9\%) were Pseudomonas aeruginosa and 5 (6.4\%) were Proteus mirabilis. Escherichia coli was the most common bacteria for asymptomatic bacteriuria in female university undergraduates in this study. Statistical analysis showed that bacteriuria rate among the students residing in different hostels was not significantly different in any of the sampled hostels $(P>0.05)$. The incidence of the bacteriuria in a healthy population is of significant public health concern as they may be incubating pathogenic microorganism which may cause disease they may be incubating pathogenic Microorganism which may cause disease when they interact with the opposite sex. Thus, education and awareness on the need for proper personal hygiene should be encouraged.
\end{abstract}

Keywords: Bacteriuria, Microorganism, Pathogenic, Asymptomatic.

\section{Introduction}

Asymptomatic bacteriuria is a condition in which urine culture reveals significant growth of pathogens that is greater than $10^{5}$ bacterial $/ \mathrm{ml}$, but the patients show no symptom of urinary tract infection (UTI).
The term 'bacteriuria' refers to the presence of bacteria in urine. It may results from contamination during or after collection of urine or it may indicate the presence of bacteria in the bladder. To distinguish between these possibilities; Kass, (2005) introduced the term "significant bacteriuria" which was defined as the 
occurrence of $10^{5}$ or more bacteria per $\mathrm{ml}$ of a voided clean catch midstream urine aseptically collected, Bacteriuria can be divided into symptomatic and asymptomatic.

Asymptomatic bacteriuria therefore refers to the presence and multiplication of bacteria pathogen in the bladder urine that is greater than $10^{5}$ bacterial $/ \mathrm{ml}$ in the absence of symptoms of urinary tract infection(UTI) while symptoms are present in symptomatic cases (Kunin, 2005). The frequency of asymptomatic bacteriuria varies among different populations, depending on factors such as age, sex, area of residence and underlying disorders, pregnancy, obstruction of urinary flow and underlying diseases, Ojiegbe \& Nworie 2000). Frank-Peterside \& Wokoma, (2009). Stamm and Hooton, (1993) referred asymptomatic disease as that which may involve only the lower tract or both the lower and upper urinary tract. Infections are "uncomplicated" when they occur in a normal urinary tract with no structural, functional or underlying host illness to account for the infection, or "complicated" when an underlying abnormality is thought to have enabled the infection to occur Krieger,(2002). Infection may involve single sites such as urethra to cause urethritis, prostrate to cause prostitis, bladder, to cause cystitis, kidney to cause pyelonephritis but the whole system is always at a risk of invasion by bacteria once any part is infected moreover, pyuria as evidenced by the inflammation of the genitourinary tract. The organisms most frequently isolated in asymptomatic bacteriuria and urinary tract infection includes species of Enterobacteriaceae especially Escherichia coli which is predominant, followed by, Staphylococcus aureus, Klebsiella, pneumoniae Pseudomonas aeruginosa, Enterococcus faecalis, and Proteus species (Nicolle et al., 2005).

The study is aimed at isolating and identifying the bacterial etiologic agent responsible for asymptomatic bacteriuria in females and to identify the chief organism that causes UTI.

\section{Materials and Methods}

This study was carried out in Rivers State University of Science Technology Nkpolu, Port
Harcourt, Rivers State, Nigeria.Port Harcourt is the capital of Rivers State located at south-south part of Nigeria. The State has approximately 5 million people, "Rivers state last known population (year, 2015)," and is bounded in the South by the Atlantic ocean in the West by Bayelsa and Delta and in the North by Imo, Abia and Anambra and in the East by Akwa-Ibom states. Rivers State University of Science Technology is situated at Nkpolu-Oroworukwo Port Harcourt in Port Harcourt Local Government Area.

\section{Study Population}

The study population comprised of 100 female undergraduate students of Rivers State University of Science and Technology residing in different hostels within the school campus. Who showed no symptoms of urinary tract infections and those who were not on antibiotic therapy at the time of sample collection, or who had not taken antibiotics within one month prior to sampling. The samples were collected into sterile, widemouthed and screw capped sample bottles.

Cultures were done on cysteine lactose electrolyte deficiency medium, colony counts yielding bacteria growth of $10^{5} / \mathrm{ml}$ or more of pure isolate were deemed significant. The isolates were identified using gram staining reactions and biochemical reactions such as coagulase, catalase, indole, citrate, urease and sugar fermentation.

\section{Results}

Out of 100 urine specimens cultured, a total of 78 specimens had bacteria isolates and identified comprising of Escherichia coli 33(42.3\%), Staphylococcus aureus 22(28.27\%), Klebisella pneumoniae 11(4.1\%), Pseudomonas aeruginosa $7(8.9 \%)$ and protein mirabils $5(6.4 \%)$. Escherichia coli was the most common bacteria isolated followed by Staph.aureus and Klebsiella for asymptomatic bacteria in female university undergraduates in this study. The total prevalence rate of bacteriuria was $78 \%$ with the highest rate occurring in students within age group of 21-23, $42(80.8 \%)$. 
Also the distribution of isolates with respect to the hostels in the PG hostel has the highest prevalence rate followed by Hostel $\mathrm{C}$ and Hostel $\mathrm{D}$ while Hostel $\mathrm{H}$ has the lowest prevalence as shown in Table 1. The prevalence rate of infection were higher among single students compared to married students as shown in Figure 1. While infection rate was highest among age group 2123, age group 27-30 returned the lowest prevalence of infection as shown in Table 2 .

Table 1: The distribution of isolates with respect to hostels

\begin{tabular}{lccccccc}
\hline Hostel & $\begin{array}{c}\text { Number of } \\
\text { students }\end{array}$ & $\begin{array}{c}\text { E.coli } \\
(\boldsymbol{\%})\end{array}$ & $\begin{array}{c}\text { Staphylococcus } \\
\text { aureus }(\boldsymbol{\%})\end{array}$ & $\begin{array}{c}\text { Klebsiella } \\
\mathbf{s} \boldsymbol{p} .\end{array}$ & $\begin{array}{c}\text { Pseudomonas sp. } \\
(\boldsymbol{\%})\end{array}$ & $\begin{array}{c}\text { Proteus } \\
\text { sp. } \\
(\boldsymbol{\%})\end{array}$ & $\begin{array}{c}\text { Total No } \\
(\boldsymbol{\%}) \\
\text { infected }\end{array}$ \\
\hline Hostel PG & 40 & $14(35)$ & $9(22.5)$ & $5(12.5)$ & $4(10)$ & $2(5)$ & $34(85.0)$ \\
Hostel H & 20 & $6(30)$ & $4(20)$ & $2(10)$ & $1(5)$ & $1(5)$ & $14(70.0)$ \\
Hostel D & 20 & $7(35)$ & $4(20)$ & $2(10)$ & $1(5)$ & $1(5)$ & $15(75.0)$ \\
Hostel C & 20 & $6(30)$ & $5(25)$ & $2(10)$ & $1(5)$ & $1(5)$ & $15(75.0)$ \\
\hline Total & $\mathbf{1 0 0}$ & $\mathbf{3 3 ( 4 2 . 3 )}$ & $\mathbf{2 2 ( 2 8 . 2 )}$ & $\mathbf{1 1 ( 1 4 . 4 )}$ & $\mathbf{7 ( 8 . 9 )}$ & $\mathbf{5 ( 6 . 4 )}$ & $\mathbf{7 8 ( 1 0 0 )}$ \\
\hline
\end{tabular}

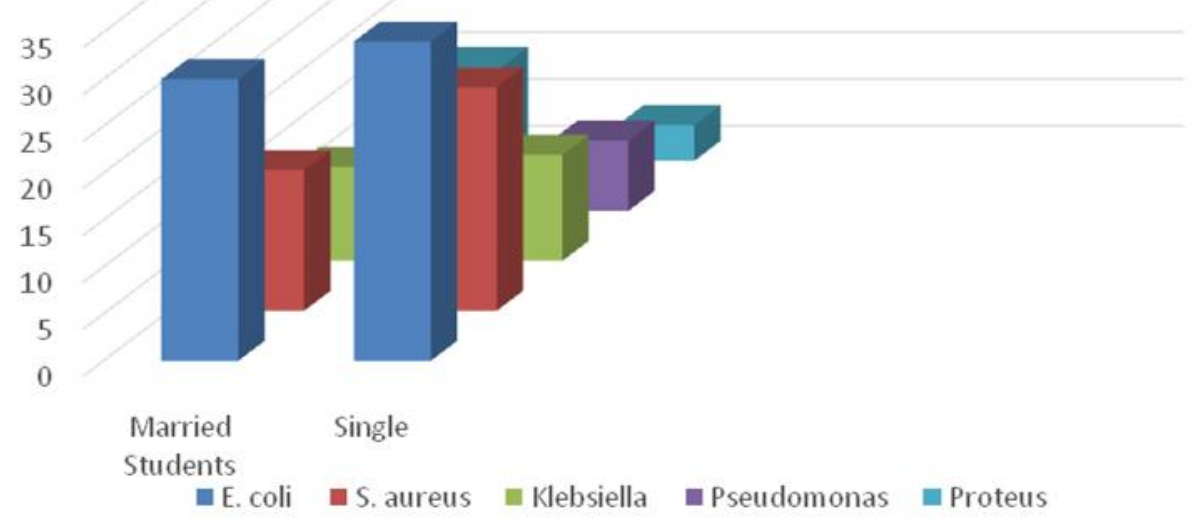

Figure 1: The distribution of isolates with respect to marital status.

Table 2: The distribution of isolates with respect to age groups.

\begin{tabular}{lccccccc}
\hline $\begin{array}{l}\text { Age } \\
\text { Group } \\
\text { (years) }\end{array}$ & $\begin{array}{c}\text { Number } \\
\text { of } \\
\text { students }\end{array}$ & $\begin{array}{c}\text { E.coli } \\
(\boldsymbol{\%})\end{array}$ & $\begin{array}{c}\text { Staphylococcus } \\
\text { aureus }(\boldsymbol{\%})\end{array}$ & $\begin{array}{c}\text { Klebsiella } \\
\text { sp. }(\%)\end{array}$ & $\begin{array}{c}\text { Pseudomonas } \\
\text { sp. }(\%)\end{array}$ & $\begin{array}{c}\text { Proteus } \\
\text { sp. } \\
(\%)\end{array}$ & $\begin{array}{c}\text { Total No } \\
\% \text { infected }\end{array}$ \\
\hline $17-20$ & 23 & $7(30)$ & $5(21)$ & $3(13)$ & $1(4)$ & $2(8.7)$ & $18(78.3)$ \\
$21-23$ & 52 & $18(34.6)$ & $12(23)$ & $6(11.5)$ & $4(7.7)$ & $2(3.8)$ & $42(80.8)$ \\
$24-26$ & 20 & $6(30)$ & $4(20)$ & $2(10)$ & $2(10)$ & $1(5)$ & $15(75.0)$ \\
$27-30$ & 5 & $2(40)$ & $1(5)$ & 0 & 0 & 0 & $3(60)$ \\
\hline Total & $\mathbf{1 0 0}$ & $\mathbf{3 3 ( 4 2 . 3 )}$ & $\mathbf{2 2 ( 2 8 . 2 )}$ & $\mathbf{1 1 ( 1 4 . 4 )}$ & $\mathbf{7 ( 8 . 9 )}$ & $\mathbf{5 ( 6 . 4 )}$ & $\mathbf{7 8 ( 7 8 . 0 )}$ \\
\hline
\end{tabular}




\section{Discussion}

Asymptomatic bacteriuria occurs frequently and is a major cause of UTI (Nurullaev, 2004). This is because under favourable conditions, asymptomatic bacteriuria progresses to symptomatic (clinical) UTI (Harrington \&Hooton 2000; Scholes, et al., 2000). Bacteria that colonize the urinary tract may ascend towards the bladder to cause cystitis, which is usually associated with the classic symptoms of UTI (which includes pain, frequency, and urgency). Urinary tract infections can proceed from the bladder, through the ureter, to the kidneys, where it can cause pyelonephritis, which may lead to irreversible kidney damage, renal failure, and death (Scholes et al., 2005).

Out of 100 samples, the prevalence of asymptomatic bacteriuria among apparently healthy female students observed in this study is $78 \%$ this is similar with previous findings in Nigeria and some other places that have demonstrated the presence of bacteria in urine without the occurrence of physical symptoms of UTI (Frank-Peterside \& Wokoma,2009 ;Mwaka, 2011; Frank-Peterside \&Oguike,2006). The prevalence of significant bacteriuria in this study of $78 \%$ is of grave concern especially since the students included in this study did not have complaints suggestive of UTI.

Considering the bacterial organisms isolated from this study, Escherichia coli was the most frequent isolate accounting for $42.3 \%$. This finding agrees with earlier reports that observed the same predominant trend in Escherichia coli infection pattern. This could be due to the fact that female students within this age range of sample collection (17-30) are sexually active with multi sex partners which may predispose them to UTI (Cheesbrough, 2004). This also explains why unmarried subjects had higher prevalence rate than the married. Another reason could be as a result of poor genital hygienic practices by female students who may find it difficult to clean their anus properly after defecating (front to back) or clean their genital after passing urine.
Escherichia coli is the most prevalent organism isolated as the causative agents of asymptomatic bacteriuria. This is followed by Staphylococcus aureus. There was a significant difference in the prevalence of asymptomatic bacteriuria with respect to age group. Age group 21-23 (80.8\%) and $17-20(78.3 \%)$ respectively (Table 1$)$. The aforementioned age groups having the highest infection was also observed in previous studies. Though there is no significant difference in the prevalence of asymptomatic bacteriuria with respect to the different hostels some observational studies suggest that persons with untreated asymptomatic bacteriuria are at increased risk of developing symptomatic urinary tract infections and other complications. This evidence is inconclusive, however, the clinical outcomes are caused by bacteriuria (especially in the absence of a structural abnormality), hence early detection and treatment results in important clinical benefits.

The findings of this study have highlighted the need to include assessment of asymptomatic bacteriuria as part of the Medical examination for students, especially new entrants, in tertiary institutions. Ordinarily such students would not attend a clinic, although as we have observed, they could be carrying an asymptomatic bacteriuria infection. It is also important to note that if this routine check is not done those that are asymptomatic today could be symptomatic tomorrow depending on the immune status of the student. If adequate diagnosis and treatment are not done on time, the students could also act as a reservoir host and has the capacity of infecting others, whether male or female that may come incontact with them.

\section{References}

Cheesbrough, M. 2004. District Laboratory Practice in Tropical Countries (Part 2). Cambridge University Press: Cambridge, 115.

Frank-Peterside, N. \& Oguike, N. (2006). Asymptomatic significant bacteriuria among students of the University of Port-Harcourt Nigeria. Nigerian Journal of Microbiology, 20(3), 1252-1257. 
Frank-Peterside, N. \& Wokoma, E. C. (2009). Prevalence of asymptomatic bacteriuria in students of University of Port Harcourt Demonstration Secondary School. Journal of Applied Sciences and Environmental Management, 13 (2), 55-58.

Harrington, R.D., \& Hooton, T.M. (2000).Urinary tract infection risk factors and gender. The journal of gender-specific medicine, 3(8), 2734.

Kass, E.H.(1957). Bacteriuria and the diagnosis of infections of the urinary tract. Journal of International Medicine, 100, 709-14

Krieger, J.N. (2002). Urinary tract infections. The Journal of Urology, 168, 2351-2358.

Kunin, C.M. (1994). Urinary Tract Infections in Females. Journal of Clinical Infectious Diseases 18(1), 1-10.

Mwaka, A.D. (2011). Bacteriuria among adult non-pregnant women attending Mulago hospital assessment Centre in Uganda. Journal of African Health Sciences, 11(2), 182-189.

Nicolle, L.E., Bradley, S. Colgan, R. Rice, J.C., Schaeffer, A., \& Hooton, T. M. (2005).
Infectious Diseases Society of America guidelines for the diagnosis and treatment of asymptomatic bacteriuria in adults. Journal of Clinical infectious diseases.40, 643-654.

Nurullaev, R.B. (2004). The role of asymptomatic bacteriuria in epidemiologic study of the urinary tract infection. Medscape Journal of Medicine, 7, 23-25.

Ojiegbe, G.C., \& Nworie, W.C.(2000). Asymptomatic bacteriuria among school pupils in Enugu Area. Journal of Medical Laboratory Science, 9(1),42-46.

Scholes, D. (2005). Risk factors associated with acute pyelonephritis in healthy women. Journal of Internal Medicine, 142(1), 20-27.

Scholes, D. (2000). Risk factors for recurrent urinary tract infection in young women. Journal of Infectious Disease, 182(4), 11771182.

Stamm, W.E., \& Hooton, T.M. (1993). Management of UTIs in adults. New England Journal of Medicine, 239, 1328-1334.

\begin{tabular}{|c|l|}
\hline \multicolumn{2}{|c|}{ Access this Article in Online } \\
\hline 国 & Website: \\
www.ijcrims.com \\
& $\begin{array}{l}\text { Subject: } \\
\text { Medical }\end{array}$ \\
\hline Quick Response Code & Bacteriology \\
\hline
\end{tabular}

\section{How to cite this article:}

Mbata C. A., Aleru C. P., Azike C. A., Adewoye M. O., Emeka E. E., Ugwueze V. (2016). Incidence of asymptomatic bacteriuria amongst female students residing in school hostels of Rivers state University of Science and Technology, Port Harcourt. Int. J. Curr. Res. Med. Sci. 2(10): 55-59.

DOI: http://dx.doi.org/10.22192/ijcrms.2016.02.10.005 